\title{
ANALISIS WACANA KRITIS PEMBERITAAN TENTANG ORMAS ISLAM PADA SITUS BERITA ONLINE
}

\author{
Gigit Mujianto $^{\mathrm{a}^{*}}$ \\ ${ }^{a}$ Universitas Muhammadiyah Malang \\ J1. Raya Tlogomas 246 Malang, Indonesia \\ *gigitm67@gmail.com
}

\begin{abstract}
Abstrak: Penelitian ini bertujuan mendeskripsikan strategi wacana penulis/wartawan pada teks berita 'ormas Islam' dalam menampilkan pihak-pihak dan aktor di situs berita online. Strategi wacana yang dimaksud meliputi proses eksklusi (exclusion) dan proses inklusi (inclusion). Penelitian ini menggunakan metode analisis wacana kritis yang menekankan pada bagaimana peneliti melihat keajegan isi komunikasi, membaca simbol-simbol, memaknakan isi interaksi simbolik yang terjadi dalam komunikasi. Data dalam penelitian ini menggunakan strategi wacana dalam teks berita 'ormas Islam' pada situs berita online detik.com menggunakan dimensi teks. Hasil penelitian menunjukkan bahwa pemberitaan ormas Islam di media massa menggunakan proses (1) eksklusi yang mencakup (a) pasivasi dan (b) nominalisasi, serta proses (2) inklusi yang mencakup (a) diferensiasi, (b) objektivitasabstraksi, (c) kategorisasi, (d) determinasi, dan (e) asimilasi.
\end{abstract}

Kata kunci: proses eksklusi, proses inklusi, stigma, ormas Islam

Abstract: It is the purpose of the study to describe the discourse strategy of writers / journalists in presenting parties and actors in the news texts about Islamic organizations in online news sites. The discourse strategy substituted the process of exclusion and the process of inclusion. This study employed a critical discourse analysis method that emphasized on how the researcher looked at the content of communication, read the symbols, interpreted the contents of symbolic interactions occurring in the communication. The data in this study used the discourse strategy in the news text about Islamic organizations on detik.com online news site using the text dimension. The results showed that the coverage of Islamic organizations in the mass media used several processes, namely (1) exclusion which includes (a) passivation and (b) nominalization, as well as (2) inclusion which constitutes (a) differentiation, (b) objectivity-abstraction, (c ) categorization, (d) determination, and (e) assimilation.

Keywords: exclusion process, inclusion process, stigma, Islamic organizations

\section{PENDAHULUAN}

Linguistik merupakan sebuah ilmu yang mengkaji tentang seluk-beluk bahasa. Sebagai salah satu disiplin ilmu yang berkembang, linguistik tidak dapat terlepas dari disiplin ilmu lain yang relevan seperti ilmu budaya, sastra, sosial, politik, hukum, psikologi, dan lain-lain. Hal ini dikarenakan orientasi linguistik tidak hanya mengkaji produk bahasa sebagai sesuatu yang bersifat otonom saja, melainkan juga mengkaji alat interaksi sosial masyarakat pada 
umumnya. Sarana komunikasi yang digunakan dalam setiap masyarakat mencakup bahasa yang berbeda, dialek yang berbeda, register yang berbeda, dan berbagai saluran komunikasi yang berbeda (misalnya, lisan tulisan, isyarat) (Mujianto, 2013: 13).

Bahasa senantiasa membentuk subjeksubjek, strategi-strategi, dan tema-tema wacana tertentu. Singkatnya, bahasa merupakan ruang bagi pergelaran kuasa-kuasa tertentu. Dengan demiki an, bahasa juga bisa dianggap sebagai cerminan dari situasi dan kinerja politik suatu bangsa. Hal ini mendapat penegasan dari Pabottinggi (dalam Latif dan Idi Subandy Ibrahim, 1996: 18) yang menyatakan bahwa bahasa takkan pernah lepas dari politik, betapa phobia pun sebagian di antara kita akan kata "politik" itu. Memilih memakai bahasa atau katakata tertentu, menekankan pengertian tertentu atas kata, bahkan memakai dialek tertentu tak lain dari berpolitik dalam maknanya yang paling dalam dan luas.

Plato menyatakan bahwa ketika penguasa menjadi otoriter, maka bahasa sudah hampir pasti akan menjadi kacau balau dan juga mengacaubalaukan. Jika kecenderungan otoriter penguasa hampir pasti mengacaukan bahasa, maka sumber kekacauan ada dua. Pertama, penguasa itu sendiri; kedua, kaum oposan. Untuk melanggengkan struktur dan mempertahankan status quo, penguasa akan melakukan manipulasi sosio-politis lewat manipulasi pemakaian bahasa. Sebaliknya, kaum oposan menentang fenomena tersebut dengan menciptakan counter manipulasi. Terjadinya kekacauan bahasa bermulai dari realitas pergulatan sosio-politis antara penguasa (negara) dengan masyarakat (oposan). Semuanya ini akan terpantul dalam ekspresi bahasa (Borgias dalam Tubiyono, 160).

Kita pun merayakan pembebasan publik dari dominasi pemaknaan realitas yang dilakukan istana melalui penguasaan pers dan aparatus ideologi lainnya selama beberapa dasawarsa. Publik konsumen industri media kini seolah telah memasuki symbolic hypermarkets, yang dalam hal ini mereka memiliki kebebasan penuh untuk memilih dan sekaligus memaknai kesemua teks yang dijajakan pers lokal ataupun luar. Namun sebenarnya telah seberapa dekatkah kita saat ini dengan situasi komunikasi yang kita idealkan?

Memang ada sesuatu yang baru dalam diri pers di Tanah Air beserta realitas simbolik yang diproduksinya. Ada pula sesuatu yang tidak lagi seperti dulu dalam diri publik konsumen industri media. Namun ada banyak hal lain, yang tetap seperti tempo hari, bahkan semakin kuat dan telanjang. Basis sistem produksi yang melahirkan teks-teks isi media tetap yang dulu juga, yakni yang digerakkan oleh dinamika sirkuit moneycommodity-more money. Sementara suprastruktur produksi segala teks itu sendiri kini semakin nyata terisi oleh sebuah ramuan aneh, hasil kombinasi antara rasionalitas formal (rasionalitas yang instrumental bagi tujuan maksimalisasi keuntungan dan akumulasi modal, dalam bingkai sebuah metanarasi yang melihat ketimpangan struktur sosial sebagai suatu hal alami), dengan rasionalitas substansif yang bisa dengan mudah terisi oleh ideologi patriarki, dan berbagai sentimen rasialisme serta primordialisme.

Namun yang penting untuk dimengerti dalam soal itu adalah perbedaan antara kuasa atas teks dengan kuasa atas struktur yang dalam hal ini teks dikonstruksi, dipresentasi, dan dimaknai. Artinya, konsumen dan pekerja industri pers memang mempunyai pilihan bagaimana membuat dan memaknai teks, yang semua itu tidak dilakukan dalam bingkai struktur pilihanpilihan yang mereka susun sendiri, melainkan yang terbentuk di luar jangkauan intervensi mereka (Eriyanto, 2005: vii-viii).

Menurut John Fiske, makna tidak intrinsik ada dalam teks itu sendiri. Seseorang yang membaca suatu teks berita tidak menemukan mkana dalam teks, sebab yang dia temukan dan hadapi secara langsung adalah pesan dalam teks. Makna itu diproduksi lewat proses yang aktif dan dinamis, baik dari sisi pembuat maupun kahalyak pembaca. Pembaca dan teks secara bersama-sama mempunyai andil yang sama dalam memproduksi 
pemaknaan, dan hubungan itu menempatkan seseorang sebagai satu bagian dari hubungannya dengan sistem tata nilai yang lebih besar tempat dia hidup dalam masyarakat. Pada titik inilah ideologi bekerja (Eriyanto, 2005: 87)

Teks dipandang sebagai sarana sekaligus media tempat suatu kelompok mengunggulkan diri sendiri dan memarjinalkan kelompok lain. Pada titik inilah representasi memegang peranan penting. Istilah representasi itu sendirimerujuk pada bagaimana seseorang, suatu kelompok, gagasan, atau pendapat tertentu ditampilkan dalam pemberitaan. Representasi ini penting dalam dua hal. Pertama, apakah seseorang, kelompok, atau gagasan tersebut ditampilkan sebagaimana mestinya. Kata 'semestinya' ini mengacu pada apakah seseorang atau kelompok itu diberitakan apa adanya, ataukah diburukkan. Penggambaran yang tampil bisa jadi adalah penggambaran yang buruk dan cenderung memarjinalkan seseorang atau kelompok tertentu. Di sini hanya citra yang buruk yang ditampilkan, sementara citra atau sisi yang baik luput dari pemberitaan. Kedua, bagaimana representasi tersebut ditampilkan. Dengan kata, kalimat, aksentuasi, dan bantuan foto macam apa seseorang, kelompok, atau gagasan tersebut ditampilkan dalam pemberitaan kepada khalayak (Eriyanto, 2005: 113).

Kita sering kali merasa adanya ketidakadilan dalam berita mengenai pemerkosaan terhadap wanita. Bagaimana pihak yang menjadi korban ini digambarkan secara buruk, sehingga khalayak tidak bersimpati dan justru lebih bersimpati kepada laki-laki yang menjadi pelaku pemerkosaan. Theo van Leeuwen membuat suatu model analisis yang bisa dipakai untuk melihat bagaimana peristiwa dan aktor-aktor sosial tersebut ditampilkan dalam media, dan bagaimana suatu kelompok yang tidak punya akses menjadi pihak yang secara terusmenerus dimarjinalkan.

Analisis van Leeuwen secara umum menampilkan bagaimana pihak-pihak dan aktor (bisa seseorang atau kelompok) ditampilkan dalam pemberitaan. Pertama, melalui proses eksklusi (exclusion). Apakah dalam suatu teks berita, ada kelompok atau aktor yang dikeluarkan dalam pemberitaan, dan startegi wacana apa yang dipakai untuk itu. Proses pengeluaran ini, secara tidak langsung bisa mengubah pemahaman khalayak akan suatu isu dan melegitimasi posisi pemahaman tertentu. Kedua, melalui proses inklusi (inclusion). Kalau eksklusi berhubungan dengan pertanyaan bagaimana proses suatu kelompok dikeluarkan dari teks pemberitaan, maka inklusi berhubungan dengan pertanyaan bagaimana masing-masing pihak atau kelompok itu ditampilkan lewat pemberitaan (Eriyanto, 2005: 172-173).

Dalam kondisi saat ini, Model Theo van Leeuwen ini dapat diaplikasikan untuk menganalisis teks-teks berita tentang ormas Islam dengan stigma intoleran yang dilatarbelakangi peristiwa kerusuhan antar-ormas pada periode waktu sebelumnya. Peristiwa itu dimulai pada 6 Februari 2011, yaitu kerusuhan dan pembantaian jemaah Ahmadiyah dan kerusuhan pasca persidangan di Pengadilan Negeri Tumenggung. Rakyat kemudian marah terhadap perbuatan yang menewaskan 3 orang warga. Namun, bukan berusaha untuk menyelesaikan secara komprehensif. Negara malah sibuk mencari kambing hitam dan menutup-nutupi peristiwa tersebut. Entah benar atau salah, adanya ormas yang terlibat, Pemerintah mewacanakan pembubaran ormas-ormas yang terbukti anarkhis (SKH Jambi Ekspress, 14 Februari 2011).

Selang beberapa tahun kemudian, tepatnya 8 Mei 2017, Pemerintah melalui Menko Polhukam Wiranto telah memutuskan untuk membubarkan dan melarang kegiatan yang dilakukan oleh organisasi kemasyarakatan (ormas) Hizbut Tahrir Indonesia (HTI). Menko Polhukam Wiranto menuturkan, keputusan tersebut telah melalui satu proses pengkajian yang panjang. Dalam keputusan tersebut, Wiranto memaparkan tiga alasan pemerintah membubarkan HTI. Pertama, sebagai ormas berbadan hukum, HTI tidak melaksanakan peran positif untuk mengambil bagian dalam proses pembangunan guna mencapai tujuan nasional. Kedua, kegiatan 
yang dilaksanakan HTI terindikasi kuat telah bertentangan dengan tujuan, azas, dan ciri yang berdasarkan Pancasila dan UUD Negara Republik Indonesia tahun 1945 sebagaimana diatur dalam Undang-Undang Nomor 17 Tahun 2013 tentang Ormas. Ketiga, aktivitas yang dilakukan HTI dinilai telah menimbulkan benturan di masyarakat yang dapat mengancam keamanan dan ketertiban masyarakat, serta membahayakan keutuhan NKRI (SKH Kompas, 8 Mei 2017).

Melalui media massa, stigma ormas intoleran tersebut diciptakan melalui citracitra buruk tentang agama dan tokoh agama (ulama). Melalui situs berita online yang sangat digemari masyarakat dengan cepat citra buruk itu menyebar. Tidak seperti media cetak, lebih efisien dan akurat, serta lebih mudah diakses oleh khalayak kapan saja dan dimana saja dan harus terhubung jaringan internet. Wacana yang disajikan dalam situs berita online sangatlah terkini dan mengikuti peristiwa yang sedang dialami di masyarakat.

Media massa mulai tidak segan lagi mengungkapkan berita-berita fiktif tentang ulama. Di saat yang sama gerakan kekerasan agama diangkat tinggi-tinggi seolah-olah gerakan radikal mewakili semua pemeluk Muslim yang taat. Pendekatan media massa yang demikian mengikuti Teori Charles Kimball. Satu kasus tertentu yang menimpa individu Muslim atau salah tokoh agama disimpulkan secara gegabah sebagai sebagai citra umum para pemeluk agama Islam (Hasib, 2017).

Dengan analisis eksklusi dan inklusi pada teks berita tentang ormas Islam, diharapkan dapat menghasilkan deskripsi strategi wacana media yang menampilkan citra buruk ormas Islam. Fenomena ini memberikan tanda bahwa betapa semangatnya media massa mengangkat atribut dan simbol-simbol Islam bukan untuk kebaikan, justru sebaliknya, ingin dicitrakan sedemikian rupa sebagai 'tersangka', terdakwa untuk segala hal buruk seperti radikalisme, terorisme, intoleran, dan kekerasan untuk kepentingan politik tertentu (Nashir, 2017).
Berdasarkan uraian di atas, penelitian ini mengambil judul "Analisis Wacana Kritis Pemberitaan tentang Ormas Islam pada Situs Berita Online”. Melalui judul tersebut penelitian ini bertujuan melakukan analisis wacana kritis pemberitaan tentang ormas Islam dengan menggunakan proses eksklusi dan inklusi dari Theo Van Leeuwen. Penelitian ini memfokuskan pada kedua unsur tersebut dalam menganaisis berita yang disajikan oleh situs berita online.

\section{METODE}

Penelitian ini menggunakan metode analisis wacana kritis yang menekankan pada bagaimana peneliti melihat keajegan isi komunikasi, membaca simbol-simbol, memaknakan isi interaksi simbolik yang terjadi dalam komunikasi. Istilah simbol merupakan kalimat generik yang dapat ditafsirkan secara filosofis, ideologik, mistik, dan kultural. Karena itu, Turner dalam Bungin (2003: 150) memberikan tiga ciri khas simbol. Pertama, simbol memiliki banyak arti dan menunjuk pada banyak hal (multivokal). Kedua, simbol memiliki arti yang bisa saling bertentangan (polarisasi). Ketiga, simbol yang bersifat umum memungkinkan adanya penyatuan dari berbagai penafsiran yang ada (unifikasi).

Dalam hal ini Kuntowijoyo mengatakan bahwa simbol tidak dapat dipisahkan dari struktur sosial, gaya hidup, sosialisasi, agama, mobilitas sosial, organisasi kenegaraan, dan seluruh perilaku sosial. Itulah sebabnya, tanpa mempelajari sistem simbol suatu masyarakat, maka sulitlah mempelajari perilaku atau kebudayaan suatu masyarakat dengan baik, dan untuk menangkap makna kebudayaan perlulah mengetahui terlebih dahulu cara menafsir simbol-simbol yang setiap saat dan tempat dipergunakan orang dalam kehidupan umum.

Sesuai dengan teori independensi teks Karl R. Popper yang menyatakan bahwa setiap monopoli pengarang dan penggagasnya, lalu masuk dalam dunia pengetahuan objektif. Dia menjadi teks yang otonom dan tidak lagi 
bergantung pada orang yang semula menggagas dan mengeluarkannya. Tafsiran terhadap sesuatu yang telah diumumkan dapat saja berbeda dari apa yang semula diniatkan dan dimaksudkan oleh penggagasnya. Dengan demikian, analisis wacana menggunakan pendekatan konstruksionisme. Fokus dari pendekatan ini adalah bagaimana pesan politik dibuat/diciptakan oleh komunikator dan bagaimana pesan itu secara aktif ditafsirkan oleh individu sebagai penerima. Menurut Eriyanto dalam Bungin (2003: 155), pendekatan konstruksionis memusatkan perhatian kepada bagaimana seseorang membuat gambaran mengenai sebuah peristiwa politik, personalitas, konstruksi yang membentuk realitas politik.

Ada dua karakteristik penting dari pendekatan konstruksionis. Pertama, pendekatan konstruksionis menekankan pada politik pemaknaan dan proses bagaimana seseorang membuat gambaran tentang realitas politik. Kata makna itu sendiri merujuk kepada sesuatu yang diharapkan untuk ditampilkan, khususnya melalui bahasa. Makna bukanlah sesuatu yang absolut, konsep statik yang ditemukan dalam suatu pesan. Makna adalah suatu proses aktif yang ditafsirkan seseorang dalam suatu peran.

Kedua, pendekatan konstruksionis memandang kegiatan komunikasi sebagai proses yang terusmenerus dan dinamis. Pendekatan konstruksionis tidak melihat media sebagai faktor penting, karena media itu sendiri bukanlah sesuatu yang netral. Perhatian justru lebih ditekankan pada sumber dan khalayak. Dari sisi sumber(komunikator), pendekatan konstruksionis memeriksa proses bagaimana pesan ditampilkan, dan dalam sisi penerima ia memeriksa bagaimana konstruksi makna individu ketika menerima pesan. Pesan dipandang bukan sebagai mirror of reality yang menampilkan fakta suatu peristiwa apa adanya. Dalam menyampaikan pesan, elit menyusun suatu citra tertentu atau merangkai ucapan tertentu dalam memberikan gambaran tentang realitas politik. Seorang komunikator dengan realitas yang ada akan menampilkan fakta tertentu kepada publik, memberikan pemaknaan tersendiri terhadap suatu peristiwa dalam konteks pengalaman, pengetahuannya sendiri.

Analisis wacana secara teoretis juga tidak dapat dipisahkan dengan pendekatan interaksi simbolis, karena prinsip yang melandasi filsafatnya dan pendekatan metodologinya sama. Bagian yang penting dari teori interaksi simbolik ialah konstruk tentang "diri". Diri itu tidak dilihat sebagai yang berada dalam individu seperti "aku" atau "kebutuhan yang teratur", "motivasi", dan "norma", serta "nilai" dari dalam. Diri adalah definisi yang diciptakan orang (melalui interaksi dengan yang lainnya) di tempat ia berada. Dalam mengkonstruk atau mendefinisikan aku, manusia mencoba melihat dirinya sebagai orang lain, melihatnya dengan jalan menafsirkan tindakan dan isyarat yang diarahkan kepada mereka dengan jalan menempatkan dirinya dalam peranan orang lain. Jadi, diri itu juga merupakan knstruk sosial, yaitu hasil persepsi seseorang terhadap dirinya dan kemudian mengembangkan definisi melalaui proses interaksi. Cara ini memberikan kesempatan bagi orang untuk bertumbuh dan berubah sepanjang mereka lebih banyak belajar tentang dirinya melalui proses interaksi tersebut. Cara konseptualisasi diri ini mengarahkan pada penelitian tentang self-fulfilling prophecy dan menyediakan latar belakang tentang apa yang dinamakan labelling approach terhadap perilaku menunjang (Moleong, 2002: 12-13).

Melalui bahasalah berbagai tindak misrepresentasi tersebut ditampilkan oleh media dan dihadirkan dalam pemberitaan. Eriyanto (2003: 15) menyatakan bahwa bahasa, baik pilihan kata maupun struktur gramatika, dipahami sebagai pilihan, mana yang dipilih oleh seseorang untuk diungkapkan membawa makna ideologi tertentu. Ideologi itu dalam taraf yang umum menunjukkan bagaimana satu kelompok berusaha memenangkan dukungan publik, dan bagaimana kelompok lain berusaha dimarjinalkan lewat pemakaian struktur gramatika tertentu. Dalam penelitian ini unit analisisnya adalah pilihan kata mapun struktur gramatika pada teks berita tentang 'ormas Islam' pada laman berita online detik.com bulan Januari s.d. Desember 2017. Laman berita online detik. 
com merupakan laman yang sudah lama menjadi laman paling banyak diakses oleh orang Indonesia, baik lewat PC maupu android. detik.com resmi didirikan pada tanggal 9 Juli 1998 oleh Budiono Darsono (eks wartawan Detik, Yayan Sopyan (eks wartawan Detik. dan sekarang detik menjadi dikenal masyarakat luas karena berisi berita lengkap tentang olahraga, politik, ekonomi, resep, teknologi dan lain sebagainya. detik.com ini sangat difavortikan para pebisnis sampai para petani untuk kepentingan "mendapatkankan informasi" yang bermanfaat.

Data strategi wacana dalam teks berita 'ormas Islam' pada situs berita online detik.com menggunakan dimensi teks. Dimensi teks dengan model analisis Theo van Leeuwen meliputi unit analisis pilihan kata dan struktur gramatika pada teks berita tentang 'ormas Islam'. Unit analisis ini berada dalam lingkup strategi dalam proses eksklusi dan inklusi dengan berbagai bentuknya. Proses eksklusi terurai melalui bentuk pasivasi, nominalisasi, dan penggunaan anak kalimat, Adapun proses inklusi terurai melalui bentuk diferensiasi-indiferensiasi, objektivasiabstraksi, nominasi-kategorisasi, nominasiidentifikasi, determinasi-indeterminasi, asimilasiindividualisasi, dan asosiasi-disosiasi.

Menurut van Leeuwen dalam Eriyanto (2005: 191-193), ada dua hal yang perlu diperhatikan ketika kita menganalisis data terkait aktor sosial dalam suatu pemberitaan. Kesatu, eksklusi: apakah dalam teks berita itu aktor sosial dihilangkan atau disembunyikan dalam pemberitaan? Kalau ya, bagaimana strategi yang dilakukan oleh media dalam menyembunyikan atau mengeluarkan aktor sosial tersebut? Pengeluaran/penghilangan aktor ini berakibat macam-macam yang di antaranya dapat melindungi subjek/pelaku dalam suatu proses pemberitaan. Kedua, inklusi: bagaimana aktor yang disebut itu ditampilkan dalam pemberitaan. Dalam inklusi, aktor (seseorang/kelompok) tersebut dimasukkan/disebut dalam pemberitaan, lalu bagaimana cara penggambarannya? Meskipun aktor tidak dihilangkan, proses marjinalisasi seseorang atau kelompok tertentu tetap bisa dilakukan. Van Leeuwen memberikan serangkaian strategi wacana bagaimana strategi wacana itu dapat dipakai sedemikian rupa sehingga mempengaruhi makna yang sampai ke pikiran pembaca. Ketiga, membuat interpretasi hasil analisis dengan memberikan ekstrapolasi dan pemaknaan (meaning). Dalam hal ini ekstrapolasi lebih menekankan pada kemampuan untuk menangkap hal dibalik yang tersajikan, sedangkan memberikan makna merupakan upaya lebih jauh dari penafsiran, yang mempunyai kesejajaran dengan ekstrapolasi (Muhadjir, 1996: 138). Secara umum, apa yang ingin dilihat dari model van Leeuwen ini dapat digambarkan sebagai berikut.

Tabel 1

Strategi Wacana van Leeuwen

\begin{tabular}{clllll}
\hline TINGKAT & \multicolumn{5}{c}{ YANG INGIN DILIHAT } \\
\hline Eksklusi & $\begin{array}{l}\text { Apakah ada aktor } \\
\text { disembunyikan dalam pemberitaan. }\end{array}$
\end{tabular}

Misalnya dalam berita mengenai demonstrasi mahasiswa, apakah semua aktor yang terlibat diberitakan secara menyeluruh, apakah ada upaya media untuk hanya mengedepankan satu aktor dan menghilangkan aktor lain? Apakah efek dari penghilangan tersebut?

\section{Bagaimana strategi yang dilakukan untuk menyembunyikan atau menghilangkan} aktor sosial tersebut?

Misalnya dalam berita mengenai demonstrasi mahasiswa tersebut, polisi sebagai pelaku penembakan dihilangkan/disembunyikan. Strategi apa yang dilakukan? Apakah strategi tersebut dilakukan secara sengaja oleh media ataukah melewati suatu proses yang tidak disadari oleh penulis/wartawan? 
Inklusi

Dari aktor sosial yang disebut dalam berita, bagaimana mereka ditampilkan? Dan dengan strategi apa pemarjinalan atau pengucilan itu dilakukan?

Misalnya dalam berita mengenai kekerasan terhadap wanita. Kalau pelaku kekerasan misalnya disebut dalam teks berita, bagaimana aktor itu disebut? Apakah penggambaran tersebut berkaitan dengan proses marjinalisasi atau pengucilan aktor tertentu dalam pemberitaan? Kalau ya, dilakukan dengan cara dan strategi yang bagaimana?

\section{HASIL PENELITIAN}

\section{Penggunaan Strategi Wacana dalam Proses Eksklusi (Exclusion)}

\section{Pasivasi}

Pasivasi adalah proses bagaimana suatu kelompok atau aktor tertentu tidak dilibatkan dalam suatu pembicaraan atau wacana. Penghilangan aktor ini untuk melindungi dirinya. Salah satu cara klasik adalah dengan membuat kalimat dalam bentuk pasif. Lewat pemakaian kalimat pasif, aktor dapat tidak dihadirkan dalam teks, sesuatu yang tidak mungkin terjadi dalam kalimat yang berstruktur aktif. Bentuk pasif ini terdapat dalam teks berita yang berisi pernyataan Direktur Ormas Kementerian Dalam Negeri, La Ode Ahmad tentang UU Ormas.

Dalam (revisi UU) Ormas ini kan diatur semacam larangan, yaitu agar ormas tidak mengembangkan paham yang bertentangan dengan Pancasila. Nah, sekarang mau kita perjelas larangan itu bagaimana sehingga tidak terjadi multitafsir," ucap Direktur Ormas Kementerian Dalam Negeri La Ode Ahmad dalam diskusi yang digelar Himpunan Mahasiswa Islam di Graha Dipo Insan Cita, Jalan Sultan Agung, Jakarta Selatan, Senin (13/3/2017) (Detik/13 Maret 2017).

Pada teks pernyataan di atas, aktor yang membuat larangan agar ormas tidak mengembangkan paham yang bertentangan dengan Pancasila tidak dihadirkan dalam teks. Untuk maksud demikian, digunakan kata kerja bentuk pasif 'diatur'. Penggunaan bentuk pasif yang diikuti dengan dalih memperjelas larangan itu agar tidak terjadi multitafsir ini menghadirkan stigma ormas telah mengembangkan paham yang bertentangan dengan Pancasila.

Bentuk pasif juga terdapat dalam teks berita yang berisi pernyataan Menteri Dalam Negeri, Tjahjo Kumolo ketika berbicara tentang Pembubaran Ormas.

Hizbut Tahrir Indonesia (HTI) dipastikan Menteri Dalam Negeri Tjahjo Kumolo sebagai ormas yang terdaftar di Kementerian Hukum dan HAM, bukan di Kemendagri. Meski begitu, legalitas HTI sebagai ormas bisa dicabut bila HTI bersikap anti-Pancasila (Detik/02 Mei 2017).

Pada teks berita di atas, aktor yang mencabut legalitas HTI sebagai ormas tidak dihadirkan dalam teks. Untuk maksud demikian, pernyataan penulis berita menghadirkan kata kerja bentuk pasif 'dicabut'. Penggunaan bentuk pasif yang tidak diikuti dengan dalih itu menghadirkan stigma ormas bersikap anti-Pancasila.

Teks berita yang berisi pernyataan Kepolisian Negara Republik Indonesia oleh Kadiv Humas Mabes Polri, Irjen Boy Rafli Amar tentang UU ormas juga menggunakan bentuk pasif.

Di tempat yang sama, Kadiv Humas Mabes Polri Irjen Boy Rafli Amar menyebut selama ini UU ormas sudah cukup baik. Menurutnya, revisi UU Ormas itu dilakukan sebagai bentuk penyempurnaan (Detik/13 Maret 2017).

Pada teks berita di atas, aktor yang melakukan revisi UU Ormas tidak dihadirkan dalam teks. Untuk maksud demikian, penulis 
berita menghadirkan kata kerja bentuk pasif 'dilakukan'. Kehadiran bentuk pasif ini tidak disertai dalih dan stigma.

\section{Nominalisasi}

Sesuai dengan namanya, strategi ini berhubungan dengan mengubah kata kerja (verba) menjadi kata benda (nomina). Umumnya dilakukan dengan memberi imbuhan pe-an. Hal ini ada hubungannya dengan transformasi dari bentuk kalimat aktif. Dalam struktur kalimat yang berbentuk aktif, selalu membutuhkan subjek. Kalimat aktif juga selalu berbentuk kata kerja, yang menunjuk pada apa yang dilakukan (proses) oleh subjek. Sebaliknya, kata benda tidak membutuhkan subjek, karena ia bisa hadir mandiri dalam kalimat. Nominalisasi bukan hanya bisa menghilangkan posisi subjek, bahkan ia dapat mengubah makna kalimat, karena nominalisasi pada dasarnya adalah mengubah kata kerja yang bermakna tindakan/kegiatan menjadi kata benda yang bermakna peristiwa. Nominalisasi ini terdapat dalam teks berita tentang UU Ormas melalui pernyataan Direktur Ormas Kementerian Dalam Negeri, La Ode Ahmad.

Menurut La Ode, aturan itu penting karena ada potensi ormas-ormas yang menjadi wadah berkembangnya paham yang berlawanan dengan Pancasila. Selain itu, La Ode menyebut revisi UU Ormas itu penting terkait dengan proses pendaftaran ormas yang belum terintegrasi dengan baik (Detik/13 Maret 2017).

Aktor yang terlibat proses pendaftaran ormas dalam teks berita di atas tidak dihadirkan. Penulis berita lebih memilih menegaskan pentingnya peristiwa revisi UU Ormas untuk membenahi pendaftaran ormas yang belum terintegrasi. Pemilihan yang dilakukannya dengan menggunakan kata benda 'pendaftaran' dan berdalih pendaftaran ormas yang belum terintegrasi tersebut membawa pembaca pada stigma bahwa ormas merupakan wadah berkembangnya paham yang berlawanan dengan Pancasila.

Nominalisasi juga terdapat pada teks berita yang berisi pernyataan Wakil Ketua Laskar Merah Putih, Iwan Cahyono tentang persekusi ormas.

Di awal dialog, Wakil Ketua Laskar Merah Putih, Iwan Cahyono, langsung menyampaikan penolakan keberadaan FPI di Kota Semarang. Ia juga mengungkapkan kekecewaan terhadap pribadi Zaenal yang kini merupakan salah satu komisioner Komisi Informasi Publik tapi justru menjadi bagian ormas FPI (Detik/14 April 2017).

Dengan memilih bentuk nominalisasi, penulis berita tersebut tidak bermaksud menunjukkan aktor di belakang persekusi ormas tersebut, tetapi lebih memfokuskan pada makna kalimat yang merujuk pada peristiwa penolakan ormas. Untuk maksud demikian, penulis berita memilih kata benda 'penolakan' untuk mengarahkan pembaca pada peristiwa penolakan keberadaan FPI di Kota Semarang. Peristiwa yang dimunculkan untuk memberikan pembenar atas penolakan terhadap FPI di kota Semarang, yaitu adanya anggota komisioner Komisi Informasi Publik yang menjadi bagian FPI.

Nominalisasi juga digunakan pada topik berita Persekusi Ormas pada teks berita yang berisi pernyataan Komisi Informasi Publik, Zaenal Petir.

Sementara itu Zaenal Petir mengatakan demi keamanan, FPI menaati hukum. Menurutnya pengusulan FPI Kota Semarang sudah dilakukan dan akan dikirim ke FPI ke Jakarta lengkap dengan nama pejabatnya. Namun demi keamanan FPI rela membubarkan acara itu (Detik/14 April 2017).

Nominalisasi tersebut dimaksudkan untuk memberikan penekanan bahwa meskipun acara pengukuhan cabang FPI di Kota Semarang dibubarkan polisi, nama-nama pejabat FPI Kota 
Semarang sudah diusulkan dan akan dikirim ke FPI Jakarta. Dalam kasus ini, nominalisasi bukanlah dimaksudkan untuk menghilangkan posisi subjek, karena posisi subjek di situ tidak ditempati oleh pemimpin FPI. FPI sebagai subjek telah disebutkan secara berulang dalam dalih pembubabaran acara pengukuhan, yaitu demi keamanan dan menaati hukum.

\section{Penggantian Anak Kalimat}

Dengan tujuan yang sama dengan nominalisasi, yaitu menghilangkan posisi subjek, strategi ini dilakukan dengan memakai anak kalimat sebagai pengganti subjek. Penampilan anak kalimat itu bisa menghilangkan keberadaan subjek, karena penulis/wartawan umumnya percaya dan menganggap bahwa khalayak pembaca tahu siapa yang menjadi aktor. Karena dianggap tahu, dan untuk efisiensi kata, aktor sebagai pelaku dihilangkan. Sekilas dengan perubahan ini tidak mengubah maksud yang ingin disampaikan oleh wartawan. Akan tetapi, perubahan itu tanpa disadari membuat subjeknya tersembunyi dalam kalimat.

Strategi ini digunakan penulis berita yang berisi pernyataan Koordinator Aliansi Pergerakan Islam (API) Jawa Barat, Asep Syaripudin tentang aksi ormas yang menuntut penghentian kriminalisasi ulama.

Berkaitan dengan persoalan yang bergulir saat ini, API Jabar bersama ormas Islam lainnya menuntut segala kasus hukum yang disangkakan pada ulama dihentikan. Sehingga tidak menimbulkan konflik yang bekepanjangan (Detik/02 Juni 2017).

Kehadiran anak kalimat 'tidak menimbulkan konflik yang bekepanjangan' menghilangkan keberadaan subjek pembuat konflik karena memperkarakan ulama. Dalam hal ini keberadaan subjek tersembunyi dalam anak kalimat yang juga berfungsi sebagai dalih dari pernyataan sebelumnya. Jadi pernyataan agar kriminalisasi ulama dihentikan diikuti dengan dalih, tidak diikuti dengan menghadirkan subjek pembuat konflik. Fakor penyebab pilihan ini adalah penulis berita memandang dalih lebih penting dimunculkan dibanding menghadirkan aktor yang sebenarnya sudah menjadi rahasia umum.

\section{Penggunaan Strategi Wacana dalam Proses Inklusi (Inclusion)}

\section{Diferensiasi}

Suatu peristiwa atau seorang aktor bisa ditampilkan dalam teks secara mandiri, sebagai suatu peristiwa yang unik atau khas, tetapi bisa juga dibuat kontras dengan menampilkan peristiwa atau aktor lain dalam teks. Hadirnya (inclusion) peristiwa atau kelompok lain selain yang diberitakan itu, bisa menjadi penanda bagaimana suatu kelompok atau peristiwa direpresentasikan dalam teks. Penghadiran kelompok atau peristiwa lain itu secara tidak langsung ingin menunjukkan bahwa kelompok itu tidak baik jika dibandingkan dengan kelompok lain. Ini merupakan strategi wacana bagaimana suatu kelompok disudutkan dengan menghadirkan kelompok atau wacana lain yang dipandang lebih dominan atau lebih baik. Strategi ini hadir dalam teks pernyataan Ketua Umum Pengurus Besar Nahdlatul Ulama (PBNU) KH Said Aqil Siroj tentang strategi dakwah.

Kiai Said membahas soal pergerakan ormas-
ormas Islam yang menyingkirkan tradisi,
melupakan sejarah panjang dakwah Islam
di Nusantara. Dia menyampaikannya lewat
kultwit di Twitter. detik.com juga telah
menghubungi Kiai Said lewat pesan singkat.
"Pergerakan ormas-ormas Islam yang
menyingkirkan tradisi, melupakan sejarah
panjang dakwah Islam di negeri ini. (Detik/28
Januari 2017)

Pernyataan di atas menampilkan kontras strategi dakwah antara ormas Islam dan Walisongo. Dalam hal ini ormas Islam ditampilkan dengan stigma berdakwah melalui kekerasan dan 
memusuhi seni-budaya tanpa pemberian dalih. Stigma ini diperkuat dengan dihadirkannya Walisongo yang memiliki strategi dakwah yang sangat bertentangan, karena dicirikan dengan dakwah yang damai, menggunakan rasa dan seni.

Tidak hanya menampilkan Walisongo yang tampil dengan kesan damai, penguatan stigma yang menyudutkan ormas Islam dinyatakan dengan membuat garis batas antara pihak 'kita' dengan pihak 'mereka', kita baik (Walisongo dan kyai) sementara mereka (ormas Islam) tidak baik.

Mereka yang berdakwah dengan kekerasan dan memusuhi seni-budaya, lupa dengan sejarah hadirnya Islam di bumi Nusantara," tulisnya lewat akun@saidaqil. Kiai Said mengatakan Walisongo pada abad ke-14 berdakwah menyebarkan ajaran Islam dengan cara damai, menggunakan rasa dan seni. "Medianya berupa wayang dan suluk-suluk yang menguatkan rasa," tulisnya. (Detik/28 Januari 2017)

Penggambaran sudut pandang 'mereka' adalah strategi wacana tertentu untuk membangun kedasaran bahwa ormas Islam dengan stigma seperti itu adalah kelompok yang tidak memberikan kontribusi pada dakwah Islam.

\section{Objektivasi-Abstraksi}

Elemen wacana ini berhubungan dengan pertanyaan apakah informasi mengenai suatu peristiwa atau aktor ditampilkan dengan memberi petunjuk yang konkret ataukah yang ditampilkan adalah abstraksi. Makna yang diterima khalayak akan berbeda, karena dengan membuat abstraksi, peristiwa atau aktor yang sebenarnya secara kuantitatif berjumlah kecil, seakan berjumlah banyak. Penyebutan dalam bentuk abstraksi ini, menurut van Leeuwen, sering kali bukan disebabkan oleh ketidaktahuan wartawan mengenai informasi yang pasti, tetapi sering kali lebih sebagai strategi wacana wartawan untuk menampilkan sesuatu.
Pada teks berita Ormas Islam informasi tentang suatu peristiwa ditampilkan melalui dua cara, yaitu dengan petunjuk yang konkret dan juga ditampilkan secara abstraksi. Dalam hal ini fokus peristiwa yang ditampilkan dengan dua startegi ini adalah mekansme pembubaran Hizbut Tahrir Indonesia (HTI). Kedua strategi tersebut muncul dari pernyataan dua kelompok yang berbeda, yaitu kelompok yang mengkritisi pembubaran HTI dan kelompok yang membubarkan HTI. Kelompok yang mengkritisi pembubaran HTI adalah dari kalangan DPR RI, yaitu Wakil Ketua Komisi II DPR, Ahmad Riza Patria. Pernyataannya menampilkan strategi objektivasi dengan menegaskan eksistensi HTI yang diatur oleh Undang-undang nomor 17 tahun 2013. Pernyataan tersebut menjabarkan mekanisme yang harus dilalui pemerintah jika ingin membubarkan orgamsa Islam yang diakui secara sah oleh undang-undang tersebut. Dalih tersebut secara objektif memberikan fakta bahwa HTI bukan organisasi liar yang dengan mudah bisa dibubarkan begitu saja.

\begin{abstract}
Wakil Ketua Komisi II DPR, Ahmad Riza Patria mengatakan ada sederet langkah yang harus dilakukan pemerintah sebelum membubarkan Hizbut Tahrir Indonesia (HTI). Pemerintah seharusnya melakukan mekanisme pemanggilan, dialog hingga pembekuan terlebih dahulu. "Ormas itu pendirian dan pembubaran diatur oleh Undang-undang nomor 17 tahun 2013. Terkait dengan pembubaran ormas itu ada mekanisme dan aturannya, seperti harus ada secara administratif terlebih dahulu, harus dipanggil, harus didialogkan, setelah itu nanti dibekukan atau diberhentikan bantuan selama 6 bulan. Baru kalau tidak ada perubahan diajukan ke pengadilan dan pengadilan yang memutuskan," ujar Riza di Gedung DPR, Senayan. (Detik/08 Mei 2017)
\end{abstract}

Langkah operasional yang harus dilakukan Pemerintah kalau ingin membubarkan HTI lebih lanjut hadir dalam teks pernyataan Yusril Ihza Mahendra. Pernyataan tersebut diperkuat 
dengan dalih yang objektif bahwa HTI adalah ormas berbadan hukum dan berlingkup nasional, sehingga dia harus mendapat kesempatan membela diri dengan mengajukan alat bukti, saksi, dan ahli untuk didengar di depan persidangan.

Langkah pemerintah memutuskan membubarkan Hizbut Tahrir Indonesia (HTI) dikritik oleh Yusril Ihza Mahendra. Mantan Mensesneg yang juga pakar tata negara itu menyebut HTI tak bisa langsung dibubarkan. "Pemerintah tidak bisa begitu saja membubarkan ormas berbadan hukum dan berlingkup nasional, kecuali lebih dulu secara persuasif memberikan surat peringatan selama tiga kali," kata Yusril dalam keterangannya. Jika langkah persuasif tidak diindahkan, kata Yusril, barulah pemerintah dapat mengajukan permohonan untuk membubarkan ormas tersebut ke pengadilan. Dalam sidang pengadilan, ormas yang ingin dibubarkan oleh pemerintah tersebut diberi kesempatan membela diri dengan mengajukan alat bukti, saksi, dan ahli untuk didengar di depan persidangan. Putusan pengadilan negeri dapat dilakukan upaya kasasi ke Mahkamah Agung. (Detik/08 Mei 2017)

Berbeda strategi dengan kelompok yang mengkritisi pembubaran HTI, kelompok yang membubarkan HTI yang dalam hal ini adalah Pemerintah, menggunakan cara abstraksi ketika menjelaskan mekanisme pembubaran HTI. Tidak ada penjelasan mengenai substansi mekanisme pembubaran, tetapi lebih kepada jumlah rapat yang dilakukan. Itu pun dengan penjelasan yang abstrak, melalui kata-kata 'sejumlah rapat', 'berkali-kali', dan 'lebih dari enam kali. Penjelasan ini ditulis tanpa diikuti dalih pelaksanaan rapat yang berkali-kali tersebut.

Menteri Dalam Negeri Tjahjo Kumolo mengatakan pengambilan keputusan untuk membubarkan HTI sudah melalui sejumlah rapat. Keputusan pembubaran itu tak mendadak. "Rapat sudah berkali-kali, rapat dengan Polhukam, diundang Pak Wiranto lebih dari enam kali kita," kata Tjahjo saat ditemui seusai konferensi pers di kantor Kementerian Koordinator Politik, Hukum, dan Keamanan, Jalan Medan Merdeka Barat, Gambir, Jakarta Pusat, Senin (8/5) (Detik/8 Mei 2017).

Strategi abstraksi ini juga terdapat dalam teks pernyataan Menteri Koordinator Politik, Hukum, dan Keamanan Wiranto. Bahkan menjadi lebih abstrak lagi ketika penjelasan mekanisme tersebut menggunakan kata-kata 'prosesnya masih panjang' meskipun disertai dalih mekanisme pembubaran akan diarahkan lewat jalur peradilan. Oleh karena itu. penggunaan dalih ini berbeda dengan kelompok yang mengkritis pembubaran HTI. Penggunaan dalih di sini dimaksudkan untuk menumbuhkan persepsei bahwa pembubaran HTI berkaitan dengan urusan peradilan, bukan untuk mengakui eksistensi HTI yang disahkan oleh undang-undang.

\begin{abstract}
Namun dia menyebut proses pembubaran HTI masih panjang. "Itu prosesnya masih panjang," kata Wiranto saat dikonfirmasi detik.com. Menurut Wiranto, karena HTI sudah berbadan hukum, mekanisme pembubaran akan diarahkan lewat jalur peradilan. Dia meminta semua pihak menunggu langkah yang akan diambil pemerintah untuk membubarkan HTI. (Detik/08 Mei 2017)
\end{abstract}

Dalih yang demikian, tentunya akan semakin mempertegas penggunaan strategi abstraksi dalam teks berita tentang pembubaran HTI. Lebih lanjut, dalih sepert itu akan mengukuhkan stigma yang diberikan oleh Pemerintah dan masyarakat kepada HTI.

\section{Kategorisasi}

Dalam suatu pemberitaan mengenai aktor (seseorang atau kelompok) atau mengenai suatu permasalahan, sering kali terjadi pilihan apakah aktor tersebut ditampilkan apa adanya, ataukah yang disebut adalah kategori dari aktor tersebut. Kategori ini bisa macam-macam yang menunjukkan ciri penting (stempel/cap) dari 
seseorang: bisa berupa agama, status, bentuk fisik, dan sebagainya. Kategori apa yang ingin ditonjolkan dalam pemberitaan, menurut van Leeuwen, sering kali menjadi informasi yang berharga untuk mengetahui lebih dalam ideologi dari media yang bersangkutan.

Pada teks berita Ormas Islam, kategorisasi banyak ditujukan pada HTI, yang dibubarkan oleh Pemerintah. Kategorisasi ini menjadi stigma yang membangun kesadaran publik ke arah persepsi yang negatif. Lebih lanjut, kategorisasi tersebut menjadi dalih pembenaran atas keputusan Pemerintah untuk membubarkan HTI. Kategorisasi pertama yang menjadi stempel/ cap HTI adalah HTI tidak melaksanakan peran positif dalam pembangunan untuk mencapai tujuan nasional. Kategorisasi ini ditampilkan dalam teks pernyataan Menko Polhukam, Wiranto.

Sebelumnya, di kantor Menko Polhukam, Jalan Medan Merdeka Barat, Jakarta, Wiranto menyebut, sebagai ormas berbadan hukum, HTI tidak melaksanakan peran positif dalam pembangunan untuk mencapai tujuan nasional (Detik/08 Mei 2017).

Kategorisasi yang kedua adalah HTI membahayakan NKRI. Kategorisasi ini ditampilkan dalam teks pernayataan Menko Polhukam, Wiranto.

Menkopolhukam Wiranto menggelar konferensi pers mengenai pembubaran Hizbut Tahrir Indonesia (HTI). Ormas itu dibubarkan karena dianggap membahayakan NKRI (Detik/08 Mei 2017).

Kategorisasi yang ketiga, HTI adalah ormas intoleransi. Kategorisasi ini ditampilkan dalam teks pernyataan Kepala Divisi Humas Polri Irjen Setyo Wasisto.

Kepala Divisi Humas Polri Irjen Setyo Wasisto menyebut intoleransi merupakan cikal bakal terorisme. Jika dibiarkan, intoleransi akan naik menjadi radikalisme dan berkembang menjadi terorisme (Detik/03Juni 2017).
Kategorisasi yang keempat, visi HTI dapat membahayakan posisi Indonesia di dunia. Kategorisasi ini ditampilkan dalam teks pernyataan Jaksa Agung HM Prasetyo.

Jaksa Agung HM Prasetyo menilai langkah
pemerintah yang ingin membubarkan ormas
Hizbut Tahrir Indonesia (HTI) sudah tepat.
Sebab, visi HTI dapat membahayakan posisi
Indonesia di dunia (Detik/05 Juni 2017).

Semua kategorisasi di atas, tidak dibenarkan oleh pihak HTI selaku ormas Islam yang dibubarkan oleh Pemerintah. Bahkan Juru bicara HTI Ismail Yusanto heran atas kajian yang dilakukan pemerintah terhadap HTI.

Juru bicara HTI Ismail Yusanto heran atas langkah pemerintah melakukan kajian terhadap HTI. Menurutnya, gerakan HTI adalah gerakan Islam yang tak bertentangan dengan Pancasila (Detik/02 Mei 2017).

Dengan demikian pemberian kategorisasi pada HTI oleh pemerintah yang tidak dibenarkan oleh HTI tersebut, masih memerlukan pertimbangan/pendapat pihak terkait atau investigasi mendalam dengan mencari fakta dan bukti-bukti yang kuat.

\section{Determinasi}

Dalam pemberitaan sering kali aktor atau peristiwa disebutkan secara jelas, tetapi sering kali juga tidak jelas (anonim). Anonimitas ini bisa jadi karena wartawan belum mendapatkan bukti yang cukup untuk menulis, sehingga lebih aman untuk menulis anonim. Bisa juga karena ada ketakutan struktural kalau kategori yang jelas dari seorang aktor tersebut disebut dalam teks. Apa pun alasannya, dengan membentuk anonimitas ini, ada kesan yang berbeda ketika diterima oleh khalayak. Hal ini karena anonimitas, menurut van Leeuwen, justru membuat generalisasi, tidak spesifik. Efek generalisasi ini makin besar kalau anonimitas dipakai dalam bentuk plural, seperti banyak orang, sebagian orang, dan sebagainya. 
Pada teks berita Ormas Islam tentang tokoh ormas, yaitu teks penyataan Menteri Dalam Negeri Tjahjo Kumolo, strategi yang digunakan untuk menampilkan tokoh ormas adalah strategi determinasi. Dengan strategi ini teks pernyataan Mendagri tersebut tidak menyebutkan nama dengan jelas, siapa tokoh tersebut. Tokoh ormas dihadirkan dengan penyebutan secara samar: 'ada mantan menteri yang juga tokoh nasional dan kini menjabat komisaris salah satu Badan Usaha Milik Negara'. Dari sini kesadaran pembaca dibawa pada kedaan menduga-duga siapa tokoh tersebut. Kesadaran pembaca digirng pada siapa tokohnya, bukan pada kebenaran fakta yang disampaikan. Orientasi berpikir tersebut menjadi semakin kuat karena pernyataan anonimitas tokoh yang dituding dengan enaknya teriak-teriak antiPancasila dan ingin mengganti dengan syariat Islam tidak diikuti dengan dalih bersasarkan fakta dan bukti-bukti yang kuat.

Menteri Dalam Negeri Tjahjo Kumolo menyebut ada mantan menteri yang juga tokoh nasional dan kini menjabat komisaris salah satu Badan Usaha Milik Negara ingin mengganti Pancasila dengan syariat Islam. Dia tak menyebut identitas sang mantan menteri. Dia hanya menyebut bahwa eks menteri itu di masa pemerintahan Presiden Joko Widodo (Jokowi) ini menjadi ketua umum salah satu organisasi besar. Tjahjo pun menyayangkan bahwa mantan menteri yang kini jadi Ketum Ormas besar itu dengan enaknya teriakteriak anti-Pancasila dan ingin mengganti dengan syariat Islam. "Bayangkan ada tokoh nasional, komisaris BUMN, zaman pak Jokowi ini jadi Ketua umum sebuah Ormas besar dengan enaknya teriak-teriak, kita anti Pancasila, Indonesia harus jadi negara Islam," kata Tjahjo kepada wartawan. (Detik/22 Mei 2017)

Anonimitas tokoh juga juga hadir pada teks pernyataan Menteri Agama ketika berbicara tentang tokoh ormas yang dituding terjerat sejumlah kasus. Tidak seperti anonimitas tokoh dalam teks pernyataan Mendagri di atas, anonimitas yang dihadirkan dalam pernyataan Menteri Agama meliputi anonimitas tokoh dan anomitas peristiwa. Dalam teks itu hanya disebutkan tokoh ormas Islam tanpa nama dan sejumlah kasus tanpa menyebutkan jenis kasusnya. Di sini pembaca harus berpikir dan menerka-nerka siapa seseorang itu dan apa kasus yang menimpa tokoh Islam tersebut. Anoimitas ganda seperti ini akan menumbuhkan pikiran bebas untuk memberi penafsiran karena absurditas tokoh dan perstiwa, yang ujungnya adalah menghadirkan stigma ormas Islam dalam kesadaran pembaca.

Menteri Agama Lukman Hakim Saifuddin menyebut sejumlah kasus yang menjerat tokoh ormas Islam belakangan ini bukan merupakan kriminalisasi ulama. Lukman menilai ini baru awal dari proses hukum. (Detik/05 Juni 2017)

Di samping anonimitas ganda, strategi anonimitas ini dipakai dengan menggunakan dalih. Namun, dalam teks pernyataan Menko Polhukam Wiranto ini dalih yang dipilih adalah dalih penyebutan tokoh ormas dengan konotasi negatif. Alih-alih memberikan fakta dan buktibukti yang kuat, konotasi negatif tersebut dimaksudkan untuk memberikan pembenaran atas kriminalisasi ulama. Dalam hal ini dalih tersebut menggiring kesadaran pembaca pada pembenaran kriminalisasi ulama bahwa tokoh ormas Islam yang saat ini tersandung kriminal adalah oknum. Kata 'oknum' yang mengiringi anonimitas inilah yang yang dapat dipersepsi dengan konotasi negatif.

Menko Polhukam Wiranto menyebut kasus yang menjerat sejumlah tokoh ormas Islam bukanlah bentuk kriminalisasi terhadap ulama. Wiranto memandang siapa pun yang tersangkut kriminal harus diproses. "Pemerintah tidak mengkriminalkan ulama. Yang kita permasalahkan bukan ulamanya tapi langkah-langkah kriminalnya itu, apakah itu ulama pedagang, politisi, kalau menyangkut masalah kriminal ya dikriminalkan," kata Wiranto di Jalan Rasuna Said, Jakarta Selatan, 
Jumat (9/6/2017). Wiranto menambahkan, masyarakat seharusnya tak menyamaratakan oknum dengan ulama. Dia berpendapat tokoh ormas Islam yang saat ini tersandung kriminal adalah oknum. "Yang kita kriminalkan itu adalah ulama yang kebetulan bermasalah dengan masalah kriminal, jadi oknum. Jangan digeneralisir," lanjutnya. (Detik/09 Juni 2017)

Konotasi negatif tersebut menimbulkan nilai rasa negatif pada seseorang ketika membaca teks pernyataan tersebut, karena oknum yang mengiringi anonimitas tokoh ormas itu memiliki makna orang atau anasir (dengan arti yg kurang baik).

\section{Asimilasi}

Strategi wacana ini berhubungan dengan pertanyaan, apakah aktor yang diberitakan ditunjukkan dengan jelas kategorinya atau tidak. Asimilasi terjadi ketika dalam pemberitaan bukan kategori aktor yang spesifik yang disebut dalam berita tetapi komunitas atau kelompok sosial tempat seseorang berada. Asimilasi pada dasarnya adalah perangkat bahasa yang memunculkan efek generalisasi. Kalimat yang mengalami asimilasi lebih cepat berpengaruh terhadap kesadaran publik. Pada teks berita ormas Islam, teks pernyataan Ketua Umum Pengurus Besar Nahdlatul Ulama (PBNU) KH Said Aqil Siroj tentang strategi dakwah menghadirkan asimilasi yang ditujukan pada suatu komunitas atau kelompok. Asimilasi tersebut diiringi dengan citra negatif: menyingkirkan tradisi, berdakwah dengan kekerasan, dan memusuhi seni budaya. Dengan citra negatif terhadap strategi dakwah tersebut, fungsi asimilasi dalam membangun kesadaran publik menjadi lebih efektif.

Kiai Said membahas soal pergerakan ormasormas Islam yang menyingkirkan tradisi, melupakan sejarah panjang dakwah Islam di Nusantara. Dia menyampaikannya lewat kultwit di Twitter, Sabtu (28/1/2017). detik. com juga telah menghubungi Kiai Said lewat pesan singkat. "Pergerakan ormas-ormas
Islam yang menyingkirkan tradisi, melupakan sejarah panjang dakwah Islam di negeri ini. Mereka yang berdakwah dengan kekerasan dan memusuhi seni-budaya, lupa dengan sejarah hadirnya Islam di bumi Nusantara," tulisnya lewat akun@saidaqil. (Detik/28 Januari 2017)

Memperkuat asimilasi dengan citra negatif juga terdapat dalam teks pernyataan Direktur Ormas Kementerian Dalam Negeri La Ode Ahmad tentang UU Ormas. Hal yang membedakan dengan teks sebelumnya adalah citra negatif yang dihadirkan lebih mengarah pada paham atau ideologi ormas Islam, yaitu wadah berkembangnya paham yang berlawanan dengan Pancasila dan tempat berkembangnya paham radikal. Dalam kesadaran publik, citra negatif itu cukup untuk membangun kesan menakutkan meskipun belum pernah melihat fakta dengan bukti-bukti yang kuat.

Menurut La Ode, aturan itu penting karena ada potensi ormas-ormas yang menjadi wadah berkembangnya paham yang berlawanan dengan Pancasila. Selain itu, La Ode menyebut revisi UU Ormas itu penting terkait dengan proses pendaftaran ormas yang belum terintegrasi dengan baik. "Ada potensi ormas yang dianggap tempat berkembangnya paham yang tidak sejalan dengan Pancasila, contohnya paham radikal. Selain itu, ada informasi proses pendaftaran ormas belum terintegrasi dengan baik. Oleh karena itu, ke depan, integrasi ini akan kita bangun," ucap La Ode. (Detik/13 Maret 2017)

Berbeda dengan kedua teks di atas, teks pernyataan Ketua Umum PP GP Ansor Yaqut Cholil Qoumas menggunakna strategi asimilasi dengan citra negatif sebagai julukan untuk ormas Islam. Jadi citra negatif tidak mengiringi asimilasi seperti pada teks sebelumnya, tetapi asimilasi dan citra negatif dihadirkan sekaligus dalam bentuk julukan ormas Islam, yaitu kelompok intoleran dan radikal. Ini tentunya jauh lebih efektif dalam membangun kesadaran pembaca tentang citra ormas Islam. 
Ketua Umum PP GP Ansor Yaqut Cholil Qoumas menyatakan Ansor siap melawan kelompok intoleran dan radikal. GP Ansor menegaskan pentingnya keutuhan NKRI dan mempertahankan Pancasila. "Ansor siap berhadapan kelompok intoleransi, kelompok ideologi impor negara lain yang masuk ke Indonesia. Ini juga tak luput dari saran beliau (Said Aqil Siroj)," kata Yaqut dalam sambutan Harlah GP Ansor ke-83 Tahun bertema 'Meneguhkan Semangat Kebangsaan, Membawa Khazanah Islam Nusantara untuk Perdamaian Dunia' di kantor Pimpinan Pusat GP Ansor, J1 Kramat Raya 65A, Jakarta Pusat, Jumat (5/5/2017). (Detik, Jumat 5 Mei 2017)

Pembaca tidak perlu lagi tahu citra negatif itu dari bagian kalimat yang lain, karena ia sudah bisa ditemukan dalam julukan yang dihadirkan sebagai stempel/cap untuk mengukuhkan stigma ormas Islam yang tidak disukai tersebut.

\section{Asosiasi}

Strategi wacana ini berhubungan dengan pertanyaan, apakah aktor atau suatu kelompok ditampilkan sendiri ataukah ia dihubungkan dengan kelompok lain yang lebih besar. Ini adalah proses yang sering kali terjadi dan tanpa kita sadari. Kelompok sosial di sini menunjuk pada tempat aktor tersebut berada, tetapi persoalannya apakah disebut secara eksplisit atau tidak dalam teks. Asosiasi menunjuk pada pengertian ketika dalam teks, aktor sosial dihubungkan dengan asosiasi atau kelompok yang lebih besar, tempat aktor itu berada. Dengan demikian, strategi asosiasi membuat makna menjadi besar (glorifikasi), karena asosiasi membuat khalayak membayangkan dan menghubungkan secara imajiner dengan komunitas yang lebih luas. Pada teks berita Ormas Islam, asosiasi hadir pada teks pernyataan pemimpin organisasi keagamaan, yaitu NU dan GP Ansor tentang pembubaran ormas. Pemakaian strategi asosiasi dalam teks pernyataan Ketua Umum PBNU KH Said Aqil Siroj dihadirkan dalam bentuk dukungan kepada Pemerintah yang membubarkan HTI.
Bahwa bukan seorang Said Aqil Siroj yang mendukung keputusan Pemerintah membubarkan HTI, tetapi NU yang memberikan dukungan tersebut. Asosiasi ini dimaksudkan untuk membangun kesadaran pada pembaca bahwa keputusan Pemerintah itu didukung oleh NU sebagai organisasi keagamaan dengan jumlah anggota terbesar. Strategi asosiasi ini diharapkan memberikan kekuatan legitimasi nonformal atas keputusan membubarkan HTI.

Ketua Umum PBNU KH Said Aqil Siroj mengapresiasi langkah pemerintah yang membubarkan Hizbut Tahrir Indonesia (HTI). Pemerintah dinilai mengambil langkah tepat dengan membubarkan ormas yang merongrong keutuhan NKRI. "Itu merupakan kebijakan yang sangat tepat. PBNU mengapresiasi dan mendukung apa yang dilakukan pemerintah," demikian dikutip detik.com dari situs resmi nu.or.id, Senin (8/5/2017). (Detik/08 Mei 2017)

Pemakaian strategi asosiasi juga terdapat pada teks pernyataan Ketua Umum PBNU KH Said Aqil Siroj ketika berbicara tentang politik masa lalu. Dalam hal ini NU sebagai organisasi keagamaan turut andil berjuang mengisi kemerdekaan bersama kelompok nasionalis. Oleh karena itu, NU tidak akan mengubah Pancasila dengan memformalkan dan mengkonstitusikan syariat Islam. Strategi asosiasi tersebut dimaksudkan untuk membangun kesadaran pembaca mengenai peran NU yang cukup besar dalam mengisi kemerdekaan. Kesadaran yang pertama ini diharapkan akan diikuti kasadaran berikutnya tentang hubungan NU dan kaum nasionalis yang harmonis.

Ketua Umum PBNU, Sa'id Aqil Siroj juga berpendapat sama. Ia mengatakan antara kelompok nasionalis dan kelompok agama harus saling mendukung, serta berjuang mengisi kemerdekaan. "Kami dahulu telah memberikan Bung Karno istilah penguasa yang sah. Jadi saat itu antara nasionalis dan NU sudah sangat saling mendukung, saling 
berjuang mengisi kemerdekaan," ucap Sa'id. Menurutnya seseorang harus menjadi nasionalis religius, orang yang taat agama dan taat nasionalis. Sa'id mengatakan agama untuk diamalkan, bukan untuk dipolitisir dan konstitusi formal negara. "Agama itu salat yang rajin, baca Quran yang baik, anak dididik dengan agama, akhlak, sopan santun. Tidak ada sedikitpun benaknya dari pengurus NU untuk mengubah Pancasila, tidak sedikit pun dari NU ataupun kami ingin menformalkan dan mengkonstitusikan syariat Islam," tutupnya. (Detik/13 Juli 2017)

Pemakaian strategi asosiasi juga digunakan dengan lebih agresif dalam teks pernyataan Ketua GP Ansor pusat Yaqut Cholil Qoumas. Dengan strategi tersebut, pembaca digiring pada suatu kedaaan yang gawat karena ormas Islam akan menghapus NKRI dan keadaan genting karena terdapat beberapa kelompok ormas Islam yang mengancam keamanan negara. Kedaan demikian kemudian dijadikan legitimasi untuk melihat ormas Islam sebagai musuh bersama.

Ketua GP Ansor pusat Yaqut Cholil Qoumas menemui Menko Polhukam Wiranto. Kedatangannya untuk mendukung pemerintah yang menerbitkan Peraturan Pemerintah Pengganti Undang-undang (Perppu) 2/2017 tentang Organisasi Kemasyarakatan (Ormas). "Kalau ada yang tidak setuju silakan mengajukan judicial review. Kan ada mekanismenya. Kalau kita mah setuju saja," ujar Cholil di kantor Kemenko Polhukam, Jalan Medan Merdeka Barat, Jakarta Pusat. Menurutnya, GP Ansor melihat penerbitan ini karena adanya ancaman. "Ancaman itu ya kelompok-kelompok itu yang mengatasnamakan islam dan menghapus NKRI." ujarnya. GP Ansor menilai, Indonesia sudah dalam keadaan genting karena terdapat beberapa kelompok yang mengancam keamanan negara. Beberapa contohnya seperti kasus bom yang menyerang sejumlah kota di Indonesia beberapa tahun terakhir. "Rentetanrentetan ini kan kalau dibiarkan makin besar," kata Cholil. Cholil berpandangan jika kelompok-kelompok yang terindikasi Islam garis keras itu memiliki keseriusan untuk meruntuhkan negara. Kelompok-kelompok itu juga menurut Cholil akan mengganti Indonesia dengan negara Islam. (Detik/18 Juli 2017)

Legitimasi tersebut diperkuat dengan kategorisasi: Islam garis keras, mengancam keamanan negara, dan serius meruntuhkan negara; dan prediksi tentang kemungkinan-kemungkinan yang bakal terjadi kalau masyarakat tidak segera mengambil tindakan terhadap ormas Islam yang sudah diberi cap/stempel: menghapus NKRI, mengganti Indonesia dengan negara Islam. Kedua cara penyampaian dalam teks pernyataan tersebut membangun kesadaran orang tentang kedaan bahaya yang akan ditimbulkan oleh ormas Islam yang sudah dicap/stempel tersebut, sehingga tidak berpikir lagi untuk mencari fakta dan bukti-bukti yang kuat, tetapi yang penting adalah bagaimana ormas Islam dengan stempel/cap negatif tersebut secepatnya dapat segera ditindak.

\section{PEMBAHASAN}

Ideologi merupakan konsep sentral dalam analisis wacana kritis Model Theo van Leeuwen. Hal ini karena teks berita, baik yang berupa percakapan maupun pernyataan adalah bentuk dari praktik ideologi atau pencerminan dari ideologi tertentu. Ideologi ini dibangun oleh kelompok yang dominan dengan tujuan untuk mereproduksi dan melegitimasi dominasi mereka. Strategi yang digunakan ada dua. Pertama, melalui proses eksklusi (exclusion). Apakah dalam suatu teks berita, ada kelompok atau aktor yang dikeluarkan dalam pemberitaan, dan strategi wacana apa yang dipakai untuk itu. Proses pengeluaran ini, secara tidak langsung bisa mengubah pemahaman khalayak akan suatu isu dan melegitimasi posisi pemahaman tertentu. Kedua, melalui proses inklusi (inclusion). Kalau eksklusi berhubungan dengan pertanyaan bagaimana proses suatu kelompok dikeluarkan dari teks pemberitaan, maka inklusi berhubungan dengan pertanyaan bagaimana masing-masing 
pihak atau kelompok itu ditampilkan lewat pemberitaan (Eriyanto 2005, 173).

Dengan memakai kata, kalimat, informasi atau susunan bentuk kalimat tertentu, cara bercerita tertentu, masing-masing kelompok direpresentasikan dalam teks. Kedua strategi itu bertujuan membangun kesadaran kepada khalayak bahwa dominasi itu diterima secara taken for granted. Teks dipandang sebagai medium saluran kelompok yang dominan memanipulasi ideologi kepada kelompok yang tidak dominan melalui kampanye disinformasi. Kampanye disinformasi dihadirkan dalam teks berita Ormas Islam berkenaan dengan stigma sumber radikalisme dan benih konflik yang membelah warga bangsa. Agama dan ormas Islam seolah jadi terdakwa (Nashir, 2017). Ormas Islam dianggap sumber radikalisme dan benih konflik yang membelah warga bangsa. Ormas Islam cenderung untuk terus menerus menjadi objek pemaknaan, dan mendapat stigma dengan stempel/cap negatif.

Dengan analisis van Leeuwen, stigma yang menjadi stempel/cap ormas Islam hadir dalam kesadaran khalayak melalui proses eksklusi dan proses inklusi. Melalui proses eksklusi, pengeluaran subjek dengan membuat dalih, dihadirkan dengan strategi: (1) pasivasi, meniadakan hadirnya aktor dalam teks; (2) nominalisasi, mengubah makna tindakan menjadi peristiwa; dan (3) penggantian anak kalimat, membuat subjek tersembunyi. Adapun melalui proses inklusi, peristiwa atau aktor disertai stigma, dihadirkan dengan strategi: (1) diferensiasi, menampilkan perbedaan yang kontras untuk menyudutkan; (2) objektivasiabstraksi, menampilkan dalih objektif dan negatif; (3) kategorisasi, menghadirkan persepsi negatif; (4) determinasi, menampilkan anonimitas, tokoh, peristiwa, dan tokoh dengan konotasi negatif; (5) asimilasi, menghadirkan citra dan julukan negatif.

Dari hasil penelitian tersebut, maka tampak stigma ditampilkan secara tidak langsung dan secara langsung. Dalam proses eksklusi, stigma ditampilkan secara tidak langsung melalui penggambaran peristiwa proses penindakan yang dilakukan oleh Pemerintah terhadap ormas Islam. Oleh karena itu, strategi lebih difokuskan pada menyembunyikan atau mengabstraksi aktor kekuasaan yang melakukan penindakan. Adapun secara langsung, stigma tampil dengan wajahnya yang buruk melalui proses inklusi. Dengan proses ini stigma hadir dengan berbagai cara, agar nampak jelas keburukannya dalam kesadaran khayak. Cara pertama, dilakukan dengan menyudutkan ormas Islam melalui apresiasi positif pada kelompok lain. Cara kedua, menampilkan berbagai dalih negatif untuk memberikan pembenaran atas tindakan yang dilakukan Pemerintah. Cara ketiga, anonimitas tokoh ormas Islam dengan memberi konotasi negatif. Cara keempat, menampilkan citra negatif suatu komunitas atau kelompok dengan menyusun kategorisasi tanpad disertai informasi fakta dan bukti yang akurat.

Pemberian stigma melalui berbagai proses inklusi di atas, selanjutnya diikuti dengan strategi asosiasi. Asosiasi yang mengacu pada organisasi keagamaan ditampilkan untuk memberikan penguatan stigma ormas Islam guna memperoleh legitimasi nonformal, baik legitimasi politik maupun legitimasi peran. Legitimasi inilah yang dijadikan modal untuk mencapai tujuan akhir dari proses kontrol terhadap media, yaitu melakukan tindakan/perlawaan yang masif terhadap ormas Islam.

\section{SIMPULAN}

Melalui proses eksklusi, aktor dikeluarkan dalam pemberitaan. Pengeluaran subjek ini dimaksudkan untuk menyudutkan ormas Islam melalui citra/kesan yang objektif dengan membuat dalih berdasarkan peristiwa, sehingga menghilangkan keberadaan subjek. Pengeluaran tersebut dihadirkan dengan strategi: (1) pasivasi, meniadakan hadirnya aktor kekuasaan dalam teks; (2) nominalisasi, mengubah makna tindakan menjadi peristiwa; dan (3) penggantian anak kalimat, membuat subjek tersembunyi. 
Melalui proses inklusi, kelompok dominan lebih memegang kendali dalam menafsirkan suatu peristiwa dan pemaknaannya, sementara kelompok lain yang posisinya rendah cenderung untuk terus-menerus sebagai objek pemaknaan, dan digambarkan secara buruk. Stigma tersebut dihadirkan dengan strategi: (1) diferensiasi, menampilkan perbedaan yang kontras untuk menyudutkan; (2) objektivasi-abstraksi, menampilkan dalih objektif dan negatif; (3) kategorisasi, mengahadirkan persepsi negatif; (4) determinasi, menampilkan anonimitas, tokoh, peristiwa, dan tokoh dengan konotasi negatif; (5) asimilasi, menghadirkan citra dan julukan negatif. Pemberian stigma melalui berbagai proses inklusi itu, selanjutnya diikuti dengan strategi asosiasi. Asosiasi yang mengacu pada organisasi keagamaan ditampilkan untuk memberikan penguatan stigma ormas Islam guna memperoleh legitimasi nonformal, baik legitimasi politik maupun legitimasi peran.

\section{DAFTAR PUSTAKA}

Bungin, Burhan (Ed.). 2003. Analisis Data Penelitian Kualitatif. Jakarta: PT RajaGrafindo Persada.

Eriyanto. 2005. Analisis Wacana. Yogyakarta: LkiS.

Hasib, Ahmad Kholili Hasib. 2017. Sihir Media dan Kampanye Anti Otoritas Agama, (Online), (https://www.hidayatullah.com/artikel/ ghazwulfikr/read/2017/02/16/111930/ sihirmedia-dan-kampanye-anti-otoritas-agama. html. diakses 30 November 2017).
Jambi Ekspress, 14 Februari 2011. Pembubaran Ormas Ditinjau dari Sudut Yuridis, (online), (http://www.jambiekspres.co.id/index. php/opini/18486-pembubaran-ormasditinjau-dari-sudut-yuridis.html, diakses 30 November 2017).

Kompas, 8 Mei 2017. Ini Alasan Pemerintah Bubarkan Hizbut Tahrir Indonesia, (online), (http://nasional.kompas.com/ $\mathrm{read} / 2017 / 05 / 08 / 14382891 /$ ini.alasan. pemerintah.bubarkan.hizbut.tahrir. indonesia, diakses 30 November 2017).

Latif, Yudi dan Idi Subandy Ibrahim (Ed.). 1996. Bahasa dan Kekuasaan: Politik Wacana di Panggung Orde Baru. Bandung: Mizan.

Moleong, Lexy J. 2002. Metode Penelitian Kualitatif. Bandung: PT Remaja Rosdakarya. Muhadjir, H. Noeng. 1996. Metodologi Penelitian Kualitatif. Yogayakarta: Rake Sarasin.

Mujianto, Gigit. 2013. 'Tuturan Pejabat Negara dalam Berita 'Korupsi' pada Media Massa Cetak". Ditulis dalam Humanity, Jurnal Penelitian Sosial Volume 8, Nomor 2, Hal. 13-20.

Nashir, Haedar. 2017. Agama Jadi Tersangka, (Online), (http://www.republika.co.id/ berita/ jurnalisme-warga/wacana/17/11/26/ ozyo51396-agama-jadi-tersangka, diakses 30 November 2017).

Tubiyono. 2001. "Dehegemonisasi Bahasa". Ditulis dalam Linguistik Indonesia, Jurnal Ilmiah Masyarakat Linguistik Indonesia Tahun 19, Nomor 2, Hal. 157-163. 